\title{
Antioxidant Activity and Hepatoprotective Effect of an Aqueous Extract of Alchornea cordifolia Leaves
}

\author{
Kouakou Etienne Effo*, Sylvain Landry Kouakou, Geneviève Irié-N'Guessan, \\ N’Doua Gisèle Kouakou-Siransy
}

Département de Pharmacologie, Pharmacie clinique et Thérapeutique, UFR Sciences Pharmaceutiques et Biologiques, Université Félix Houphouet Boigny, Abidjan, Côte d'Ivoire

Email: *effoet@yahoo.fr

How to cite this paper: Effo, K.E., Kouakou, S.L., Irié-N'Guessan, G. and Kouakou-Siransy, N.G. (2017) Antioxidant Activity and Hepatoprotective Effect of an Aqueous Extract of Alchornea cordifolia Leaves. Pharmacology \& Pharmacy, 8, 369-380.

https://doi.org/10.4236/pp.2017.811027

Received: September 20, 2017

Accepted: November 20, 2017

Published: November 23, 2017

Copyright (ङ 2017 by authors and Scientific Research Publishing Inc. This work is licensed under the Creative Commons Attribution International License (CC BY 4.0).

http://creativecommons.org/licenses/by/4.0/

\begin{abstract}
Alchornea cordifolia is a medicinal plant, whose ethanolic and methanolic extracts have shown antioxidant activity which could confer hepatoprotective effect, knowing that liver cells are attacked by free radicals. The hepatoprotective effect of these extracts has been demonstrated in models of hepatotoxicity induced by paracetamol high doses in animals. However, anti-tubercular drugs at the usual dose present hepatotoxicity risk. Could Alchornea cordifolia help to limit hepatotoxicity induced by anti-tubercular drugs? This work aimed to evaluate the antioxidant activity and the hepatoprotective effect of an aqueous extract of $A$. cordifolia leaves (AEAC). The antioxidant activity of $A$. cordifolia leaves was studied in vitro by 1,1-diphenyl-2-picrylhydrazyl (DPPH) free radicals scavenging assay and by the iron reduction ability. A phytochemical screening was carried out to identify the chemical groups that could be responsible for this activity. The hepatoprotective effect was demonstrated in a model of hepatotoxicity induced by isoniazid and rifampicin in rats. Two hours after induction of hepatotoxicity, the animals were orally administered the AEAC at $200 \mathrm{mg} / \mathrm{kg}, 400 \mathrm{mg} / \mathrm{kg}, 800 \mathrm{mg} / \mathrm{kg}$ for 10 consecutive days. A blood sample was taken on the $11^{\text {th }}$ day for the evaluation of transaminases, markers of hepatic cytolysis. A totally of 96 rats were used in this study. AEAC showed dose-dependent antioxidant activity. Phytochemical screening revealed the presence of flavonoids, tannins and alkaloids. Administrated alone, aqueous extract of $A$. cordifolia leaves didn't modificate the transaminases, isoniazid and the isoniazid + rifampicin combination resulted in increasing transaminases (ALT and AST) by more than $48 \%$. AEAC at $800 \mathrm{mg} / \mathrm{kg}$ reduced AST and ALT levels by more than $45 \%$. AEAC at $200 \mathrm{mg} / \mathrm{kg}$ and $400 \mathrm{mg} / \mathrm{kg}$ decreased ALT more than $40 \%$. Knowing that antioxidant activity protects liver, the AEAC may by its antioxidant activity, contribute to protect against the hepatotoxicity induced by an-
\end{abstract}


ti-tubercular drugs in the rat.

\section{Keywords}

Antioxidant, Hepatoprotective, Aqueous Extract, Alchornea cordifolia

\section{Introduction}

Herbal treatments are becoming increasingly important within populations. These plants are mostly endowed with antioxidant properties able to inhibit free radicals formation and to oppose macromolecules oxidation [1]. Free radicals have been implicated in a number of pathological processes, such as asthma, cancer, cardiovascular disease, cataracts, diabetes, inflammatory diseases, liver diseases and degenerative diseases [2]. Antioxidants can inhibit or retard the oxidation of an oxidizable substrate in a chain reaction [3]. The properties of these plants used in traditional medicine were attributed mainly to the presence of polyphenols [4].

Several works of our department have dealt with Alchornea cordifolia [5] [6]. A. cordifolia is a very popular herb in African traditional medicine for its many properties. Many studies have demonstrated its antioxidant properties [7] [8]. This antioxidant activity is manifested by free radical scavenging [9] [10], which can confer a hepatoprotective effect [7] [8] [11]. The liver is indeed the main organ involved in metabolism and detoxification for the excretion of various endogenous and exogenous substances. However, liver cells are prone to be attacked and necrotic by free radicals [12].

The antioxidant properties of a methanolic extract and an ethanolic extract of A. cordifolia have been studied [7] [8]. The hepatoprotective properties of these extracts have also been demonstrated against high-dose paracetamol-induced hepatotoxicity in an animal model [7] [11].

However, the antioxidant properties and the hepatoprotective effect of the aqueous extract, which is the most usual form in traditional human medicine, seem to have been little studied. In addition, the hepatoprotective effect of $A$. cordifolia has not been found in the literature against the hepatotoxicity of anti-tubercular drugs. Antitubercular drugs (isoniazid (INH) and rifampicin (RIF)) are responsible for many adverse effects in liver at the usual doses [13] [14]. These effects are cytolytic and result in an increase in serum transaminases [15] [16]. Aouam et al. (2007) [17] reported hepatic disorders in $10 \%$ to $20 \%$ of users in Tunisia with INH at therapeutic dose, when Blumberg et al. (2003) [13] reported disturbances of hepatic markers in $0.5 \%$ to $2 \%$ of patients in the USA. When the RIF was associated with the INH, this disturbance affected more patients [17], which was $2.5 \%$ to $6 \%$ of the patients according to Blumberg et al. (2003) [13].

This work aimed to evaluate the antioxidant properties and the hepatoprotective effect of an aqueous extract of $A$. cordifolia leaves in order to overcome the 
hepatotoxicity of anti-tubercular drugs in rats.

\section{Material and Method}

\section{Plant material}

The plant material consisted of leaves of Alchornea cordifolia (Schum. and Thonn.) collected at Yakasse-Mé (in the city of Adzopé about $75 \mathrm{~km}$ from Abidjan, Ivory Coast). Voucher samples (AC 2016) are kept in the Pharmacology laboratory. The leaves were authenticated at the National Floristic Center of Abidjan, affiliated to Université Félix Houphouët Boigny (Abidjan). These leaves were air-dried in the laboratory at $18^{\circ} \mathrm{C}$.

\section{Extraction method}

Fine powder of dried leaves ( $100 \mathrm{~g}$ ) was macerated for $24 \mathrm{~h}$ at room temperature in $1 \mathrm{~L}$ of distilled water. The resulting filtrate was dried in a MEMMERT oven at $60^{\circ}$ for $72 \mathrm{~h}$. The obtained dry extract (aqueous extract of Alchornea cordifolia: AEAC) was conserved at $4^{\circ} \mathrm{C}$; and aliquots of dry powder were used for pharmacological studies after being suspended in physiological saline.

\section{Animal material}

The animal material consisted of rats, Rattus norvegicus, Wistar strain weighing between $150 \mathrm{~g}$ and $220 \mathrm{~g}$. 96 rats were used for 3 series of studies. They were obtained from the laboratory animals of the Pharmacology Laboratory of the Faculty of Pharmacy and Biological Sciences of Université Félix Houphouët Boigny Abidjan (Côte d'Ivoire). All animals were kept under controlled environmental conditions of $24^{\circ} \mathrm{C} \pm 1^{\circ} \mathrm{C}$ with a cycle of 12 hours of light and 12 hours of darkness. Food and water and are given Ad libitium. Before the beginning of the experiment, they were subjected to fasting for 12 hours with free access to water.

\section{Chemicals materials used}

In this study, we used isotonic saline solution $0.9 \%$, ether (Gifrer), distilled water, anti-tubercular drugs (INH (Lupine LTD), RIF (Remedica LTD), methanol, DPPH (1,1-diphenyl-2-picrylhydrazyl) (Sigma Aldrich, Germany), ascorbic acid (Sigma Aldrich, Germany) and silymarin (Sigma Aldrich, Germany).

Silymarin was used as a reference liver protector substance in this study. It is a mixture of three flavonoids (silychristin, silydianine and silybin) used as a hepatoprotective agent. It is extracted from the seeds and fruits of Silybum marianum (Parthasarathy et al., 2007) [18].

\section{Chemical analysis}

Screening for different chemical groups was done using the method as described in the works of Békro et al. (1973) [19], Ronchetti and Russo (1971) [20] and Wagner (1983) [21].

\section{Antioxidant screening}

\section{Measurement of the reducing power of iron}

\section{Principle}

The reducing power of iron $\left(\mathrm{Fe}^{3+}\right)$ in preparations is determined according to the method described by Oyaizu M. (1986) [22] and Bougandoura and Nassima 
(2013) [23]. The iron reduction method is based on the reduction of ferric iron to iron salt by the antioxidants which give the blue color in the reaction medium at $700 \mathrm{~nm}$. The increase in the absorbance indicates an increase in the reduction of ferric iron and therefore of the reducing power of the extracts tested.

\section{Procedure}

One milliliter of the extract at different concentrations $(0.007$ to $2.5 \mathrm{mg} / \mathrm{mL})$ is mixed with $2.5 \mathrm{ml}$ of a $0.2 \mathrm{M}$ phosphate buffer solution ( $\mathrm{pH} \mathrm{6.6)}$ and $2.5 \mathrm{ml}$ of a solution of potassium ferricyanide $\mathrm{K}_{3} \mathrm{Fe}(\mathrm{CN})_{6}$ at $1 \%$. The whole was incubated in a water bath at $50^{\circ} \mathrm{C}$. for $30 \mathrm{~min}$. Then, $2.5 \mathrm{~mL}$ of $10 \%$ trichloroacetic acid has been added to stop the reaction. The tubes are centrifuged at $3000 \mathrm{rpm}$ for $10 \mathrm{~min}$.

An aliquot $(2.5 \mathrm{~mL})$ of the supernatant was combined with $2.5 \mathrm{~mL}$ of distilled water and $0.5 \mathrm{~mL}$ of a $0.1 \%$ aqueous solution of $\mathrm{FeCl}_{3}$ (Ferric Chloride); and incubated for $10 \mathrm{~min}$ at room temperature. The absorbance of the reaction medium was red at $700 \mathrm{~nm}$ against a similarly prepared white, replacing the extract with distilled water which makes it possible to calibrate the apparatus (UV-VIS spectrophotometer HACH made in USA).

The positive control was represented by a standard of an antioxidant, trolox ( 1.5 to $25 \mu \mathrm{g} / \mathrm{mL}$ ) whose absorbance was measured under the same conditions as the samples. An increase in absorbance corresponds to an increase in the reducing power of the extracts tested.

\section{DPPH radical scavenging activity \\ Principle}

The method used was described by Parejo et al. (2000) [24] which is the 1,1-diphenyl-2-picrylhydrazyl (DPPH) free radical scavenging. Indeed, the reduction of DPPH by a free radical sensor is accompanied by its passage from the violet color to the yellow color, measurable at $517 \mathrm{~nm}$. A low absorbance reflects a strong inhibition of DPPH and therefore a strong antiradical activity.

\section{Procedure}

An aliquot of $0.5 \mathrm{ml}$ of $0.1 \mathrm{mM} \mathrm{DPPH}$ in methanol was added to test tubes containing $2.5 \mathrm{ml}$ of different concentrations $(0.00625-0.1 \mathrm{mg} / \mathrm{ml})$ of the methanol extract. The reaction mixture was mixed at room temperature and held for 20 minutes. The absorbance was read at $517 \mathrm{~nm}$ against a blank. The percentage inhibition of the DPPH radical was calculated according to the formula:

$$
\text { DPPH inhibition }(\%)=\frac{(\text { Absorbance of control }- \text { Absorbance of sample })}{\text { Absorbance of the control }} \times 100
$$

\section{Hepatoprotective activity}

\section{Principle}

The study involved inducing hepatotoxicity in laboratory rats by using antitubercular drugs in different combination [25] [26], and then evaluating the effect of different preparations on hepatic markers.

\section{Procedure}

\section{Effect of AEAC on hepatotoxicity markers}

Rats of both sexes were divided into 4 batches of 6 rats each and were treated 
for 10 days as follows:

1) The rats in lot 1 (negative control) received saline solution by gavage;

2) The rats in lot 2 received AEAC at $200 \mathrm{mg} / \mathrm{kg} /$ day by gavage;

3) The rats in lot 3 received AEAC at $400 \mathrm{mg} / \mathrm{kg} /$ day by gavage;

4) The rats in lot 4 received AEAC at $800 \mathrm{mg} / \mathrm{kg} /$ day by gavage.

Hepatoprotective effect against INH-induced hepatotoxicity:

Rats of both sexes were divided into 6 batches of 6 rats each and were treated for 10 days as follows:

1) The rats in lot 1 (negative control) received saline solution by gavage;

2) The rats in lot 2 received $\mathrm{INH}(100 \mathrm{mg} / \mathrm{kg} /$ day) by gavage;

3) The rats in lots 3, 4 and 5 received AEAC (200, 400 and $800 \mathrm{mg} / \mathrm{kg})$ orally 2 hours after administration of INH (100 mg/kg/day);

4) The rats in lot 6 (positive control) received silymarin (100 mg/kg/day) orally, $2 \mathrm{~h}$ after administration of INH (100 mg/kg/day).

\section{Hepatoprotective effect against INH+RIF-induced hepatotoxicity:}

Rats of both sexes were divided into 6 batches of 6 rats each and were treated for 10 days as follows:

1) The rats in lot 1 (negative control) received saline solution by gavage;

2) The rats in lot 2 received INH (100 mg/kg/day) + RIF (100 mg/kg/day) by gavage;

3) The rats in lots 3,4 and 5 received AEAC (200, 400 and $800 \mathrm{mg} / \mathrm{kg} /$ day) orally 2 hours after administration of INH (100 mg/kg/day) + RIF (100 mg/kg/day);

4) The rats in lot 6 (positive control) received silymarin $(100 \mathrm{mg} / \mathrm{kg} /$ day) orally, $2 \mathrm{~h}$ after administration of INH (100 mg/kg/day) + RIF (100 mg/kg/day).

\section{Liver Biochemical Indices measured}

At the end of the 10 days of treatment, a blood sample was taken the $11^{\text {th }}$ day by cardiac puncture for the determination of markers of hepatotoxicity. They were alanine aminotransferase (ALT) and aspartate aminotransferase (AST) [27], using standard kits.

\section{Statistical analysis}

The results were expressed as mean \pm SD. Statistical analysis used the Wilcoxon test. The difference between the mean values was considered significant if $\mathrm{p}<$ 0.05 .

\section{Results}

\section{Extraction yield}

Extraction with distilled water (AEAC) gave $8.34 \mathrm{~g}$ of dry residue, a yield of $8.34 \%$.

\section{Result on measurement of reducing power}

Figure 1 shows the results of iron reductive ability by AEAC and trolox. The AEAC has a reducing power which increases proportionally with the concentration. The same is true of the trolox. However, the AEAC activity is statistically inferior to that of the trolox. 


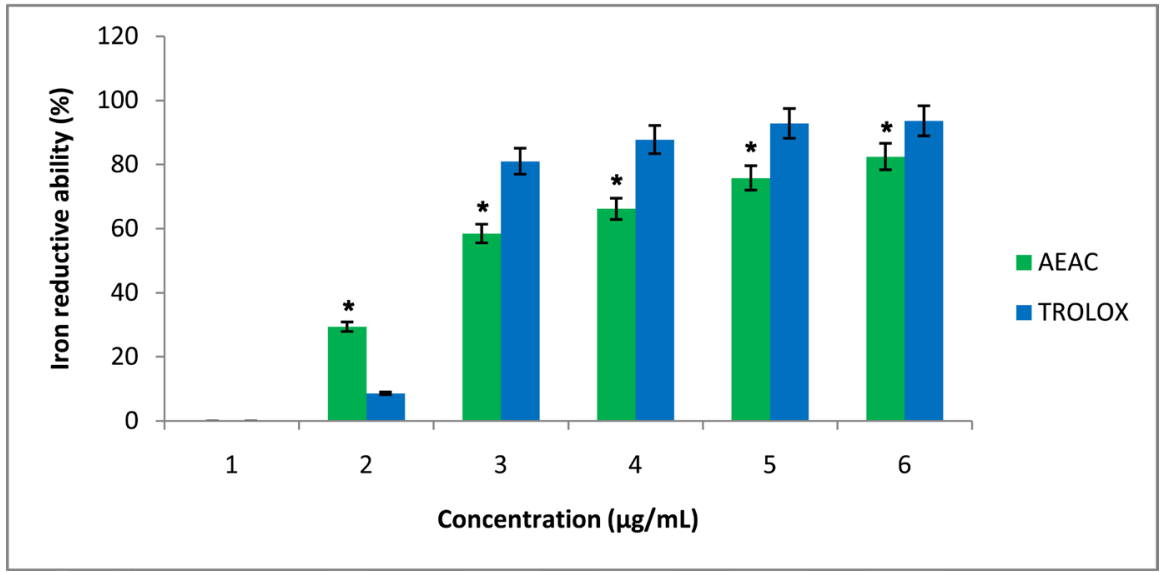

*: p < 0.05 compared to trolox; AEAC: aqueous extract of $A$. cordifolia.

Figure 1. In vitro iron reductive ability of AEAC and trolox.

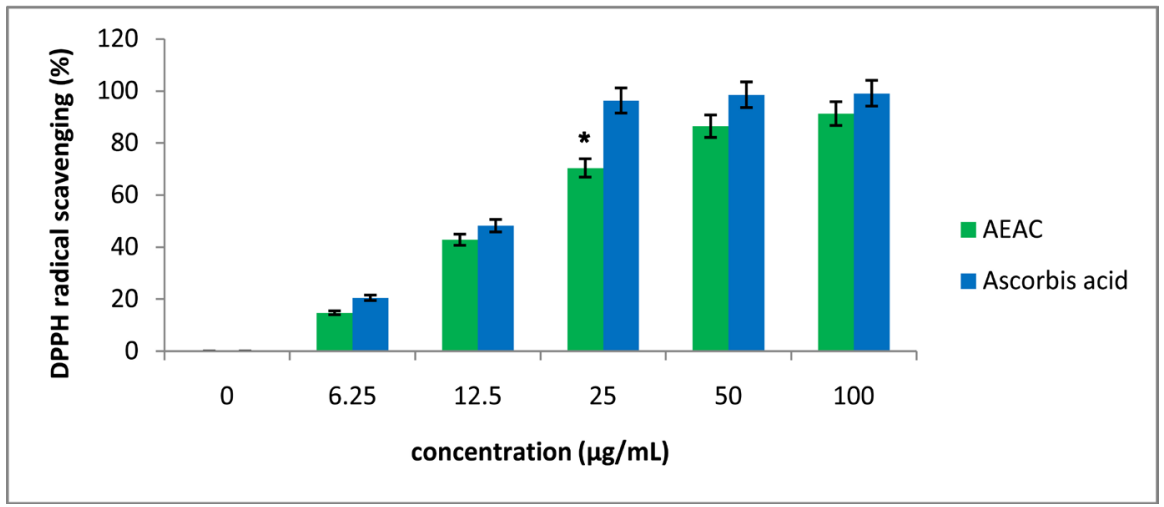

*: $\mathrm{p}<0.05$ compared to ascorbic acid; AEAC: aqueous extract of $A$. cordifolia.

Figure 2. In vitro anti-radical activity of AEAC and ascorbic acid.

\section{Measurement of anti-radical activity: DPPH}

The results of the anti-radical activity of AEAC and vitamin $\mathrm{C}$ are recorded in Figure 2. The AEAC shows an antiradical activity which increases with the concentration as well as the ascorbic acid. The anti-radical activity of the AEAC remains statistically comparable to that of the vitamin C at $100 \mu \mathrm{g} / \mathrm{mL}$.

\section{Phytochemical characterization test}

The characterization tests of the large phytochemical groups carried out on the AEAC revealed the presence of flavonoids, tannins and alkaloids, and an absence of saponosides.

\section{Results of the EAAC effect on transaminases}

The effect of AEAC alone was evaluated on serum transaminases and the various mean values are recorded in Figure 3. The different doses of AEAC alone did not increase the transaminase values compared to the $\mathrm{NaCl}_{2}$ ( $\left.\mathrm{p}>0.05\right)$.

Results on hepatoprotective effect against hepatotoxicity induced by isoniazid

The mean of transaminases values are shown in Figure 4. Isoniazid resulted in elevated transaminases (ALT and AST) $(p=0.028)$ in rats receiving it compared 


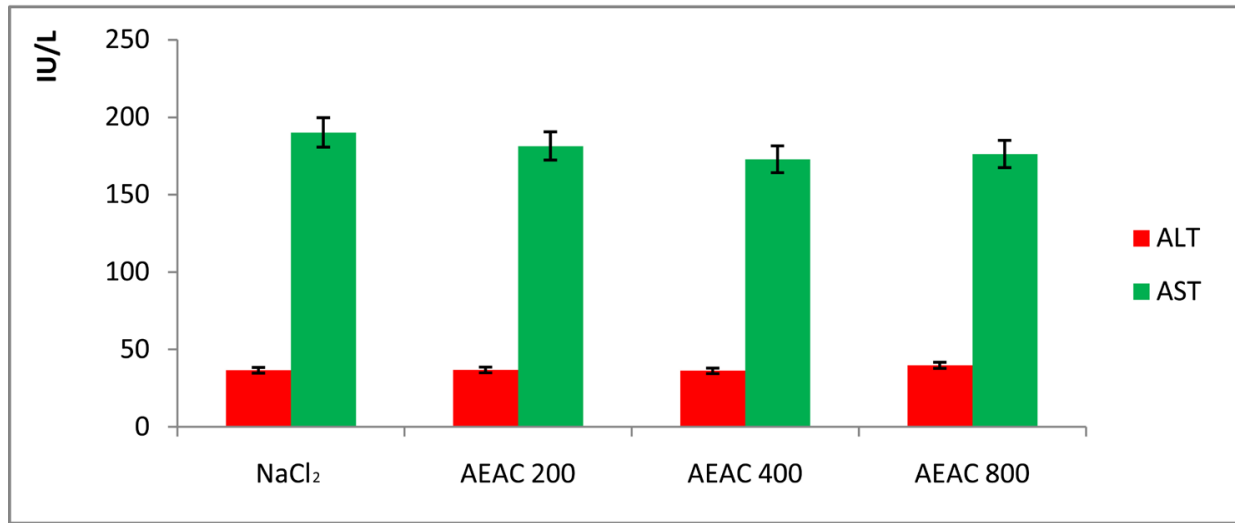

AEAC: aqueous extract of $A$. cordifolia.

Figure 3. Effect of AEAC on perturbations of serum transaminases.

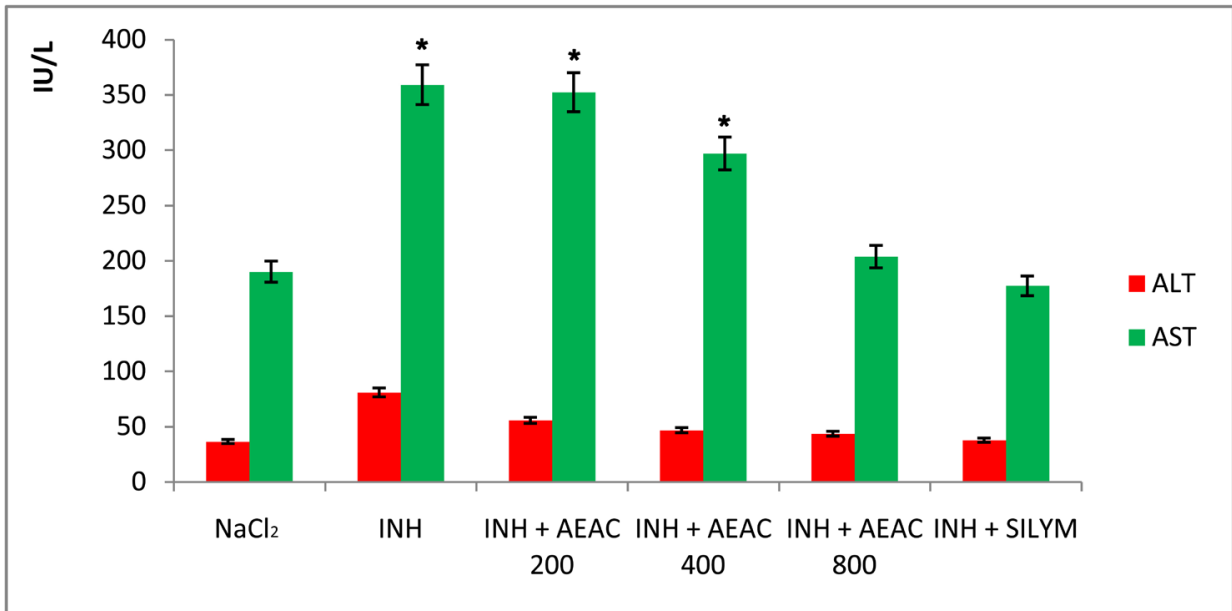

*: $\mathrm{p}<0.02$ compared to the control; INH: Isoniazid; AEAC: aqueous extract of A. cordifolia; SILYM: Silymarin.

Figure 4. Effect of AEAC on perturbations of serum transaminases induced by INH.

to rats given $\mathrm{NaCl}_{2}$. Administration of $\mathrm{AEAC}$ to $800 \mathrm{mg} / \mathrm{kg}$ and silymarin to rats significantly reduced the different values of disturbed transaminases $(p<0.05)$. The AEAC at $200 \mathrm{mg} / \mathrm{kg}$ and $400 \mathrm{mg} / \mathrm{kg}$ reduced only ALT, with AST remaining high ( $\mathrm{p}=0.143$ ). The comparison of the different doses of the AEAC between them showed a marked activity at $800 \mathrm{mg} / \mathrm{kg}(\mathrm{p}>0.05)$ on the AST. The AEAC at $800 \mathrm{mg} / \mathrm{kg}$ showed similar activity to silymarin ( $\mathrm{p}>0.05)$.

Results on hepatoprotective effect against hepatotoxicity induced by isoniazid + rifampicin

The mean of transaminases values for evaluation of liver function are shown in Figure 5. The combination of INH + RIF resulted in an elevation of ALT and AST $(p=0.02)$ in rats receiving it compared to rats given $\mathrm{NaCl}_{2}$. The administration of AEAC at $400 \mathrm{mg} / \mathrm{kg}, 800 \mathrm{mg} / \mathrm{kg}$ and silymarin in rats resulted in a significant reduction in ALT and AST disturbed levels ( $\mathrm{p}<0.05$ ), AEAC $200 \mathrm{mg} / \mathrm{kg}$ having been active only on the ALT. Comparison of AEAC to $400 \mathrm{mg} / \mathrm{kg}$ and 800 $\mathrm{mg} / \mathrm{kg}$, as well as to silymarin, showed no significant difference $(\mathrm{p}<0.05)$. 


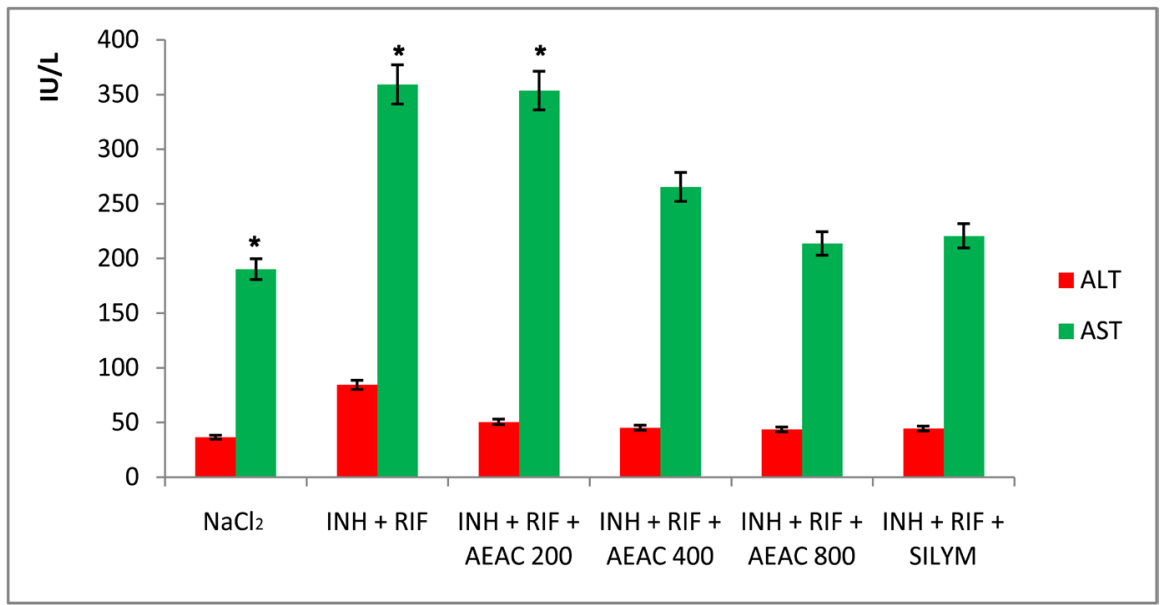

*: $\mathrm{p}<0.02$ compared to the control; INH: Isoniazid; RIF: Rifampicin; AEAC: aqueous extract of $A$. cordifolia; SILYM: Silymarin.

Figure 5. Effects of AEAC on perturbations of serum transaminases induced by INH + RIF.

\section{Discussion}

This study aimed to evaluate the in vitro antioxidant activity of an aqueous extract of $A$. cordifolia leaves and its hepatoprotective effect in vivo in rats.

The antioxidant activity of the aqueous extract of $A$. cordifolia leaves was evaluated by iron reductive ability [28] and free radical scavenging [24].

The presence of reducing agents in an extract causes the reduction of ferric iron $\left(\mathrm{Fe}^{3+}\right)$ to ferrous iron $\left(\mathrm{Fe}^{2+}\right)$. Antioxidants are considered oxidant reducing agents and inactivators [29]. Other studies have also shown that the reducing power of a compound could serve as a significant indicator of its potential antioxidant activity [30] [31].

DPPH radical involves a hydrogen atom transfer process [32]. The antiradical activity results in a donation of electrons or protons reducing the hydrazyl radical form of DPPH in non-radical form hydrazine. All substances with free radical scavenging are known as antioxidants [33]. The aqueous extract of $A$. cordifolia would trap the DPPH radical and thus could have antioxidant activity.

There is a potential antioxidant activity of the aqueous extract of $A$. cordifolia. This antioxidant activity is statistically less than that of trolox and vitamin C. Osadebe et al. (2012) [8] showed comparable antioxidant activity of the methanolic extract of $A$. cordifolia to that of vitamin $\mathrm{C}$ in their studies. Other studies on an ethanolic extract of $A$. cordifolia showed better antioxidant activity than vitamin E [7].

Comparative study of the chemical constituents revealed the presence of alkaloids, saponins, tannins, and flavonoids both in the methanolic extract [8] and in the ethanol extract [7], while the aqueous extract contained alkaloids, tannins and flavonoids. It emerges almost a similarity of the major chemical groups likely to be responsible for antioxidant activity. Indeed, Manga et al. (2004) [34] found that flavonoids possess antioxidant activities. Various other studies have shown that the 
antioxidant activity was mainly due to the presence of polyphenols [4]. Huong et al. (1998) [35] and Ince et al. (2014) [36] also showed that the saponosides were endowed with antioxidant properties. Based on this finding, a quantitative determination of the large chemical groups in these different extracts could justify the lower antioxidant activity of the aqueous extract. Since methanol and ethanol are more polar than water, they are able to extract more active ingredients from a plant, and thereby give better activity to the final extract.

This antioxidant activity of the aqueous extract of $A$. cordifolia could confer a protective effect of the liver which is subject to attack and necrosis by free radicals [12].

The study of the hepatoprotective effect of the aqueous extract of $A$. cordifolia was demonstrated using high-dose anti-tubercular drugs for 10 days in different combinations to induce hepatotoxicity in laboratory animals [25] [26]. They produce various categories of lesions in the liver, including centrilobular necrosis, hepatic cell degeneration [37]. These lesions resulted in an increase in serum transaminases [15] [16] as observed in hepatotoxic rats.

Isoniazid alone and the Isoniazid + Rifampicin combination resulted in a significant increase in ALT and AST levels. ALT and AST are two well-known diagnostic indicators of liver damage. In liver damage with hepatocellular lesions and parenchymal cell necrosis, these marker enzymes are released from damaged tissues and their levels increase in blood flow [38]. These are two hepatic enzymes linked to the subcellular functions of the mitochondria [39].

Administration of the aqueous extract of $A$. cordifolia at $200 \mathrm{mg} / \mathrm{kg}, 400 \mathrm{mg} / \mathrm{kg}$ and $800 \mathrm{mg} / \mathrm{kg}$ significantly decreased disturbed ALT values. The extract at 800 $\mathrm{mg} / \mathrm{kg}$ decreased the AST. The extract at $800 \mathrm{mg} / \mathrm{kg}$ had an effect on ALT and AST which was superposable to that of silymarin, a hepatoprotectant used as a reference in this study [18]. The lower doses of the extract were active only on ALT, which is more specific to the liver. Nonetheless, the AST values were reduced, although not significant, at these doses ( $\mathrm{p}>0.05)$.

This ability of the aqueous extract of $A$. cordifolia to lower these values may suggest hepatoprotective activity of $A$. cordifolia leaves, especially at $800 \mathrm{mg} / \mathrm{kg}$. This activity would be manifested by stabilization of the hepatic membrane and regeneration of the hepatocytes. The extract would also prevent the release of hepatic enzymes at the level of the blood stream by a reduction of the tissue lesions [40] [41].

This hepatoprotective activity of an ethanol extract and a methanolic extract of $A$. cordifolia leaves has already been demonstrated in rats against hepatotoxicity induced by paracetamol at high levels [7] [11] [42] and carbon tetrachloride [8]. The results of our work on the aqueous extract of $A$. cordifolia confirm this property of $A$. cordifolia. Moreover, at all the doses used, the aqueous extract of $A$. cordifolia was not hepatotoxic itself, in contrast to the methanolic extract which was hepatotoxic at doses greater than or equal to $800 \mathrm{mg} / \mathrm{kg}$ in of male rats [43]. More polar solvents, in addition to extracting more active ingredients for better efficiency, would also extract more toxic principles. The aqueous ex- 
tract of $A$. cordifolia would therefore be safer to use.

\section{Conclusion}

The present study demonstrated that the aqueous extract of $A$. cordifolia leaves could have antioxidant activity and confer significant protection against the hepatotoxic effects of anti-tubercular drugs.

\section{References}

[1] Iserin, P. (2001) Encyclopedia of Médicinal Plants. 2nd Edition, Larousse, Londres, $10 \mathrm{p}$.

[2] Dash, D.K., Yerigar, V.C., Nayak, S.S., Ghosh, T., Rajalingam, D., Sengupta, P., et al. (2007) Evaluation of Hepatoprotective and Antioxidant Activity of Ichnocarpus frutescens (Linn.) R. Br. on Paracetamolinduced Hepatotoxicity in Rats. Tropical Journal of Pharmaceutical Research, 6, 755-765. https://doi.org/10.4314/tjpr.v6i3.14656

[3] Alan, L. and Miller, N. (1996) Antioxidant Flavolids: Structure, Function and Clinical Usage. Alternative Medicine Review, 1, 103-111.

[4] Shiney, R.B. and Ganesh, P. (2012) Phytochemical Analysis and Comparative Effect of Cinnamomum zeylanicus, Piper nigrum and Pimpinella anisum with Selected Antibiotics and Its Antibacterial Activity against Enterobacteriaceae Family. International Journal of Pharmaceutical and Biological Archive, 3, 914-917

[5] Effo, K.E., Kouakou-Siransy, G., Irie-Nguessan, G., Sawadogo, R.W., Dally, I.L., Kamenan, A.B., Kouakou, L.S. and Kablan-Brou, J. (2013) Acute Toxicity and Antipyretic Activities of a Methanolic Extract of Alchornea cordifolia Leaves. Pharmacology \& Pharmacy, 4, 1-6. https://doi.org/10.4236/pp.2013.47A2001

[6] Kouakou-Siransy, G., Sahpaz, S., N’guessan, G.I., Datté, J.Y., Brou, J.K., Gressier, B. and Bailleul, F. (2010) Effects of Alchornea cordifolia on Elastase and Superoxide Anion Produced by Human Neutrophils. Pharmaceutical Biology, 48, 128-133. https://doi.org/10.3109/13880200903051609

[7] Olaleye, M.T., Adegboye, O.O. and Akindahunsi, A.A. (2006) Alchornea cordifolia Extract Protects Wistar Albino Rats against Acetaminophen-Induced Liver Damage. African Journal of Biotechnology, 5, 2439-2445.

[8] Osadebe, P.O., Okoye, F.B.C., Uzor, P.F., Nnamani, N.R., Adiele, I.E. and Obiano, N.C. (2012) Phytochemical Analysis, Hepatoprotective and Antioxidant Activity of Alchornea cordifolia Methanol Leaf Extract on Carbon Tetrachloride-Induced Hepatic Damage in Rats. Asian Pacific Journal of Tropical Medicine, 289-293.

[9] Lin, C.C. and Huang, P.C. (2002) Antioxidant and Hepatoprotective Effects of Acanthopanax senticosus. Phytotherapy Research, 14, 489-494.

[10] Repetto, M.G. and Llesuy, S.F. (2002) Antioxidant Properties of Natural Compounds Used in Popular Medicine for Gastric Ulcers. Brazilian Journal of Medicine and Biological Research, 35, 523-534. https://doi.org/10.1590/S0100-879X2002000500003

[11] Olaleye, M.T., Kolawole, A.O. and Ajele, J.O. (2007) Antioxidant Properties and Glutathione Stransferases Inhibitory Activity of Alchornea cordifolia Leaf Extract in Acetaminophen-Induced Liver Injury. IJPT, 6, 63-66.

[12] Pramod, K., Deva, R.G. and Lakshmayya, R.S. (2008) Antioxidant and Hepatoprotective Activity of Tubers of Momordica tuberose Cogn. against CCl4 Induced Liver Injury in Rats. Indian Journal of Experimental Biology, 46, 510-513. 
[13] Blumberg, H.M., Burman, W.J., Chaisson, R.E., et al. (2003) American Thoracic Society/Center for Disease Control and Prevention/Infectious Discases Society of America Treatment of Tuberculosis. American Journal of Respiratory and Critical Care Medicine, 167, 603-662.

[14] Yee, D., Valiquette, C., Pelletier, M., et al. (2003) Incidence of Serious Side Effects from First Line Antituberculosis Drugs among Patients Treated for Active Tuberculosis. American Journal of Respiratory and Critical Care Medicine, 167, 1477.

[15] Nolan, C.M., Goldberg, S.V. and Buskin, S.E. (1999) Hepatotocixity Associated with Isoniazid Preventive Therapy. JAMA, 281, 1014-1018.

[16] Shakya, R., Rao, B.S. and Shrestha, B. (2004) Incidence of Hepatotoxicity Due to Antitubercular Medecines and Assessment of Risk Factors. Annals of Pharmacotherapy, 38, 1074-1079. https://doi.org/10.1345/aph.1D525

[17] Aouam, K., Chaabane, A., Loussaief, C., et al. (2007) Les effets indésirables des antituberculeux: Epidémiologie, mécanismes et conduite à tenir. [Adverse Effects of Antitubercular Drugs: Epidemiology, Mechanisms and Management.] Médecine et maladies infectieuses, 37, 253-261.

[18] Parthasarathy, R., Nivethetha, M. and Brindha, P. (2007) Hepatoprotective Activity of Caesalpinia bonducella Seeds on Paracetamol Induced Hepatotoxicity in Male Albino Rats. Indian Drugs Journal, 44, 401-404.

[19] Békro, Y.A., Békro, J.A.M., Boua, B.B., Tra, B.F.H. and Ehilé, E.E. (2007) Etude ethnobotanique et screening phytochimique de Caesalpinia benthamiana (Baill.) Herend. et Zarucchi (Caesalpiniaceae). [Ethnobotanical Study and Phytochemical Screening of Caesalpinia benthamiana (Baill.) Herend. and Zarucchi (Caesalpiniaceae).] Sciences \& Nature, 4, 217-225.

[20] Ronchetti, F. and Russo, G. (1971) A New Alkaloid from Rauvolfia vomitoria. Phytochemistry, 10, 1385-1388.

[21] Wagner, H. (1983) Drogen analyse, Dünschicht chromatographische Analyse von Arzneidrogen. [Drug Analysis, Analysis by Thin Layer Chromatography of Drugs.] Springer Verlag, Berlin, Heidelberg, New York, 522 p.

[22] Oyaizu, M. (1986) Studies on Products of Browning Reaction: Antioxidant Activities of Products of Browning Reaction Prepared from Glucosamine. The Japanese Journal of Nutrition and Dietetics, 44, 307-315. https://doi.org/10.5264/eiyogakuzashi.44.307

[23] Bougandoura, N. and Nassima, B. (2013) Direct Evidence That Oxygen-Derived Free Radicals Contribute to Postischemic Myocardial Dysfunction in the Intact Dog. Proceedings of the National Academy of Sciences, 86, 4695-1699.

[24] Parejo, I., Codina, C., Petrakis, C. and et Kefalas, P. (2000) Evaluation of Scaving Activity Assessed by Co (II)/EDTA-Induced Luminal Chemilunescence and DPPH (2,2-diphenyl-1-pycryl-hydrazyl) Free Radical Assay. Journal of Pharmacological and Toxicological Methods, 44, 507-512.

[25] Santhosh, S., Sini, T.K., Anandan, R. and Mathew, P.T. (2007) Hepatoprotective Activity of Chitosan against Isoniazid and Rifampicin-Induced Toxicity in Experimental Rats. European Journal of Pharmacology, 572, 69-73.

[26] Saraswathy, S.D., Suja, V., Prema, G. and Shyamala, D.C. (1998) Effect of Liv. 100 against Antitubercular Drugs (Isoniazid, Rifampicin and Pyrazinamide) Induced Hepatotoxicity in Rats. Indian Journal of Pharmacology, 30, 233-238.

[27] Reitman, S. and Frankel, S. (1957) A Colorimetric Method for the Determination of Serum Glutamic Oxalacetic and Glutamic Pyruvic Transaminases. American Journal of Clinical Pathology, 28, 56-63. https://doi.org/10.1093/ajcp/28.1.56 
[28] Yildirim, A., Mavi, A. and Kara, A.A. (2001) Determination of Antioxidant and Antimicrobial Activities of Rumex crispus L. Extracts. Journal of Agricultural and Food Chemistry, 9, 4083-4089.

[29] Siddhuraju, P. and Becker, K. (2007) The Antioxidant and Free Radical Scavenging Activities of Processed Cowpea (Vigna unguiculata (L.) Walp.) Seed Extracts. Food Chemistry, 101, 10-19.

[30] Jeong, S.M., Kim, S.Y., Kim, D.R., Jo, S.C., Nam, K.C., Ahn, D.U. and Lee, S.C. (2004) Effects of Heat Treatment on the Antioxidant Activity of Extracts from Citrus Peels. Journal of Agricultural and Food Chemistry, 52, 3389-3393. https://doi.org/10.1021/jf049899k

[31] Kumaran, A. and Karunakaran, R.J. (2007) In Vitro Antioxidant Activities of Methanol Extracts of Five Phyllanthus Species from India. Lebensmittel-Wissenschaft und Technologie, 40, 344-352.

[32] Kaviarasan, S., Naik, G.H., Gangabhagirathi, R., Anuradha, C.V. and Priyadarsini, K.I. (2007) In Vitro Studies on Antiradical and Antioxidant Activities of Fenugreek (Trigonella foenum graecum) Seeds. Food Chemistry, 103, 31-37.

[33] Dehpour, A.A., Ebrahimzadeh, M.A., Nabavi, S.F. and Navabi, S.M. (2009) Antioxidant Activity of Methanol Extract of Ferula assafoetida and Its Essential Oil Composition. Grasas Aceites, 60, 405-412. https://doi.org/10.3989/gya.010109

[34] Manga, H.M., Brkic, D., Marie, D.E.P. and Quetin-Leclercq, J. (2004) In Vivo Anti-Inflammatory Activity of Alchornea cordifolia. Journal of Ethnopharmacology, 92, 209-214.

[35] Huong, N.T.T., Matsumoto, K., Kasai, R., Yamasaki, K. and Waranabe, H. (1998) In Vitro Antioxidant Activity of Vietnamese ginseng Saponin and Its Components. Biological and Pharmaceutical Bulletin, 21, 978-983.

[36] Ince, S., Arslan Acaroz, D., Neuwirth, O., Demirel, H.H., Denk, B., Kucukkurt, I. and Turkmen, R. (2014) Protective Effect of Polydatin, a Natural Precursor of Resveratrol, against Cisplatin-Induced Toxicity in Rats. Food and Chemical Toxicology, 72, 147-153.

[37] Graham, G.G., Scott, K.F. and Day, R.O. (2004) Alcohol and Paracetamol. Australian Prescriber, 27, 14-15. https://doi.org/10.18773/austprescr.2004.009

[38] Nkosi, C.Z., Opoku, A.R. and Terblanche, S.E. (2005) Effect of Pumpkin Seed ( $\mathrm{Cu}$ curbita pepo) Protein Isolate on the Activity Levels of Certain Plasma Enzymes in CCl4-Induced Liver Injury in Low Protein Fed Rats. Phytotherapy Research, 19, 341-345.

[39] Dwivedi, Y., Rastogi, R., Chander, R., Sharma, S.K., Kapoor, N.K., Garg, N.K. and Dhawan, B.N. (1993) Hepatoprotective Activity of Picroliv against Carbon-Tetrachloride Induced Damage in Rats. Indian Journal of Medical Research, 92, 1995-2000.

[40] Madhu Kiran, P., Vijaya Raju, A. and Ganga Rao, B. (2012) Investigation of Hepatoprotective Activity of Cyathea gigantea (Wall. ex. Hook.) Leaves against Paracetamol-Induced Hepatotoxicity in Rat. Asian Pacific Journal of Tropical Biomedicine, 2, 352-356.

[41] Singh, K., Singh, N., Chandy, A. and Manigauha, A. (2012) In Vivo Antioxidant and Hepatoprotective Activity of Methanolic Extracts of Daucus carota Seeds in Experimental Animals. Asian Pacific Journal of Tropical Biomedicine, 2, 385-388.

[42] Arhoghro, E.M., Ikeh, C.H., Eboh, A.S. and Angalabiri-Owei, B. (2015) Liver Function of Wistar Rats Fed the Combined Ethanolic Leaf Extract of Alchornea cordifolia and costus afer in Paracetamol-Induced Toxicity. WJPR, 4, 1-12.

[43] Ajibade, T.O. and Olayemi, F.O. (2015) Reproductive and Toxic Effects of Methanol Extract of Alchornea cordifolia Leaf in Male Rats. Andrologia, 47, 1034-1040. https://doi.org/10.1111/and.12374 